\title{
Metal bioaccumulation and detoxification processes in cephalopods: a review
}

\author{
Virginie Penicaud, Thomas Lacoue-Labarthe $\uparrow$, Paco Bustamante
}

UMR CNRS 7266, Littoral Environnement et Sociétés (LIENSs), Institut du Littoral et de l'Environnement, Université de la Rochelle - CNRS, 2 rue Olympe de Gouges, 17000 La Rochelle, France

† Corresponding author: Thomas Lacoue-Labarthe UMR 7266 CNRS, Université de La Rochelle, Institut du Littoral et Environnement, 2 rue Olympe de Gouges, 17000 La Rochelle, France, +33 5464583 88, $\underline{\text { tlacouel@univ-lr.fr }}$ 


\begin{abstract}
In recent decades, cephalopods have been shown to have very high capacities to accumulate most trace elements, regardless of whether they are essential (e.g., $\mathrm{Cu}$ and $\mathrm{Zn}$ ) or non-essential (e.g., $\mathrm{Ag}$ and $\mathrm{Cd}$ ). Among the different pathways of exposure to trace elements, the trophic pathway appears to be the major route of assimilation for numerous metals, including $\mathrm{Cd}, \mathrm{Co}, \mathrm{Hg}$ and $\mathrm{Zn}$. Once assimilated, trace elements are distributed in the organism, accumulating in storage organs. The digestive gland is the main organ in which many trace elements accumulate, independent of the exposure pathway. For example, this organ can present $\mathrm{Cd}$ concentrations reaching hundreds to thousands of ppm for some species, even though this represents only a small proportion of the total mass of the animal. Such a specific organotropism towards the digestive gland, regardless of the exposure pathway, poses the question of the detoxification processes evolved by cephalopods in order to sustain high concentrations of both essential and non-essential trace elements. This paper reviews our current knowledge of trace element bioaccumulation in cephalopods, differences in pharmaco-dynamics between organs and tissues, and the detoxification processes used by cephalopods to counteract trace element toxicity. We have focussed on bioaccumulation within the digestive gland by investigating the subcellular locations of trace elements and their protein ligands.
\end{abstract}




\section{Introduction}

The increase in anthropogenic sources and emission of pollutants induces a strong contamination pressure on living organisms. Coastal and oceanic ecosystems are considered to be the final receptacle of released contaminants, especially in littoral areas that are close to wastewater discharges. Hence, persistent organic pollutants (POPs), oils (including Polycyclic Aromatic Hydrocarbons), trace elements, radionuclides, litter and debris (including plastics), and pharmaceuticals, found in most coastal areas worldwide, could result in deleterious effects, directly or indirectly affecting living resources (e.g. Williams, 1996). Among these pollutants, metallic trace elements and their potential impacts on marine biota have been extensively studied for more than 40 years (e.g. Islam and Tanaka, 2004). Nevertheless, contamination of shallow water is still a concern, as the major proportion of trace elements is trapped in coastal sediments where they can be continuously released into the water column. Moreover, the development of new metal compounds, such as nanoparticles (e.g. Baun et al., 2008), has contributed to a recent increase in the release of various trace elements into the environment (Salles et al., 2013).

Many studies have reported the trace element concentrations in marine organisms of economic interest, such as fish (McGeer et al., 2011), bivalves and gastropods (Naimo, 1995). Less data is available regarding cephalopods, despite these organisms being distributed and extensively targeted by fisheries worldwide, particularly during the past decades, in which cephalopod landings have increased concomitantly with a decrease in the abundance of small pelagic fish (Jereb et al., 2015). Their massive consumption has led to the assessment of chemical contaminants in edible species, in order to evaluate risks for human health (Nakahara et al., 1982; Rjeibi et al., 2015; Storelli, 2008; Storelli et al., 2005; Storelli et al., 2010). Since then, most research has focused on the analysis of trace element concentrations (Figure 1), and to a lesser extent, on that of organic compounds in cephalopods sampled in the field (Kawano et al., 1986; Son et al., 2015; Tanabe et al., 1984). The values recorded in cephalopod tissues have revealed the exceptional capacity of these organisms to accumulate and concentrate metals compared to other marine taxa (Figure 1), whatever their geographical origin, including contaminated (e.g., along the coast of industrialised countries) or pristine areas (e.g., in the southern Indian Ocean) (Bustamante et al., 2000; Kojadinovic et al., 2011; Martin and Flegal, 1975; Nakahara et al., 1979; Schipp and Hevert, 1978). Moreover, trace element concentrations also show large variation depending on the age, sex and maturation state of individuals, in addition to variation among species and those with different life-history traits, including diet or trophic level (Chouvelon et al., 2011; Miramand et al., 2006; Ueno et al., 2003; Won et al., 2010). Nevertheless, the high concentrations recorded in cephalopods, such as $1003 \mu \mathrm{g} . \mathrm{g}^{-1}$ wet weight of $\mathrm{Cd}$ in the digestive gland of Illex argentinus (Dorneless et al., 2007), suggests that these organisms efficiently accumulate trace elements from the environment and retain them in their tissues. To the 
best of our knowledge, the effects of such contamination on cephalopods remain poorly studied (Le Pabic et al., 2015a; Raimundo et al., 2010a; Semedo et al., 2012), even though the risks for human health appear to be limited when only the muscular parts of the organism are consumed (Rjeibi et al., 2015; Storelli, 2008; Storelli et al., 2006).

Overall, compared to bivalves, a limited number of studies have been devoted to understanding the physiological mechanisms involved in the high bioaccumulation and bioconcentration capacities for trace elements in cephalopods (Bustamante et al., 2006a; Bustamante et al., 1998b; Bustamante et al., 2002a; Costa et al., 2014; Miramand and Bentley, 1992; Miramand and Guary, 1981; Nakahara et al., 1979; Raimundo et al., 2010a, b; Raimundo et al., 2008; Rocca, 1969; Tanaka et al., 1983; Ueda et al., 1985). These studies have demonstrated strong organotropism of a number of trace elements towards the digestive gland $\left(\mathrm{Ag}, \mathrm{Cd}, \mathrm{Cu}, \mathrm{Zn}\right.$ and $\left.{ }^{210} \mathrm{Po}\right)$ and the branchial hearts and their appendages $(\mathrm{Co}, \mathrm{Fe}$, $\mathrm{V},{ }^{241} \mathrm{Am},{ }^{137} \mathrm{Cs}$ and ${ }^{237} \mathrm{Pu}$ ). These organs generally show the highest concentrations among the tissues and organs analysed. This specific organ distribution suggests that these organs play a key role in the detoxification and storage of trace elements (Bustamante et al., 1998a; Bustamante et al., 2002a; Finger and Smith, 1987; Martin and Flegal, 1975; Miramand and Bentley, 1992; Smith et al., 1984), however, our understanding of the underlying physiological mechanisms needs to be improved.

The present review focuses on the metabolism of trace elements in cephalopods, including the different bioaccumulation pathways, the distribution of metals at the tissue and subcellular levels, and the detoxification processes available to counteract the potentially toxic effects of the elevated concentrations recorded in cephalopod tissues.

\section{Metal bioaccumulation processes}

Explaining why such high concentrations of trace elements are observed in cephalopods requests to evaluate the sources of exposure, and the relative contribution of different uptake pathways in bioaccumulation. The environmental compartments in which trace elements are dispersed, entrapped or accumulated, such as the water column, sediment and prey, are all potential sources of contamination for cephalopods. Therefore, bioaccumulation results from the absorption or assimilation of bioavailable elements from the seawater and sediment (pore water), in addition to those ingested through the food. In addition, the high amount of metals recorded in tissues suggests efficient retention and/or poor elimination of accumulated trace elements.

Most cephalopod species are characterised by their "grow fast, die young" life cycle, represented by their exceptional growth rates, similar to those recorded in vertebrates (O'Dor and Webber, 1986). This trait requires a strict carnivorous regime, high prey consumption rate and efficient assimilation of 
nutrients. Hence, assimilation of trace elements through ingestion of contaminated prey most likely constitutes a major source, contributing to the high trace element concentrations found in these organisms (Bustamante et al., 1998a; Martin and Flegal, 1975). As a first argument, the interspecific comparison of $\mathrm{Cd}$ concentrations in cephalopods sampled within the same area was higher in octopus species than pelagic species (Bustamante et al., 1998a; Lahaye et al., 2005). This difference could be attributed to the contrasting levels of $\mathrm{Cd}$ in benthic prey (crustaceans and bivalves), which provides the benthic cephalopods with a much higher $\mathrm{Cd}$ concentration than the fish that constitute the preferential prey of pelagic species (Cossa and Lassus, 1989) (Figure 1). In addition, studies have demonstrated that the retention of accumulated $\mathrm{Cd}$ in the cuttlefish Sepia officinalis differed depending on its uptake route. Thus, the biological half-life $\left(\mathrm{Tb}_{1 / 2}\right)$ of dissolved ${ }^{109} \mathrm{Cd}$ is approximately 2 months, whereas dietary accumulated metal is retained in tissues for an indeterminate period (Bustamante et al., 2002b), making food the main source of Cd uptake. A similar contribution of the dietary pathway has been suggested in the loliginid squid Sepioteuthis lessoniana (Koyama et al., 2000).

Based on concentrations reported in cephalopods worldwide (Figure 2A and Table S2), ommastrephid squid displayed mean Cd levels as high as octopods, but extreme values ranging between 413-1003 $\mu \mathrm{g} . \mathrm{g}-1$ wet weight were reported in the digestive gland (approximately 1000-2500 $\mu \mathrm{g}$.g-1 dry weight) of Illex argentinus (Dorneles et al., 2007; Gerpe et al., 2000). Again, the trophic regime of this oceanic ommastrephid could explain these high values, as this species consume Cd-rich pelagic crustaceans (amphipods and euphausiids), and display an important cannibalism or predation on other cephalopod species (Santos and Haimovici, 1997). In addition, the differences in bioaccumulation capacities compared to loliginids could result from their contrasting digestive physiologies, as discussed below.

Another trace element considered to be mainly accumulated through trophic pathways in marine ecosystems is $\mathrm{Hg}$ (for review: Fitzgerald et al., 2007). Studies in the literature have reported that $\mathrm{Hg}$ concentrations are positively correlated with the age and size of cephalopods (Barghigiani et al., 2000; Monteiro et al., 1992; Pierce et al., 2008; Rossi et al., 1993; Storelli and Marcotrigiano, 1999), showing its bioaccumulation over time. In the Bay of Biscay, the $\mathrm{Hg}$ concentrations in European squid Loligo vulgaris, veined squid $L$. forbesi and the common cuttlefish Sepia officinalis have been linked to changes in their trophic niche, as assessed by the stable isotope signature (Chouvelon et al., 2011). Hence, $\mathrm{Hg}$ levels in squid are significantly increased, concomitant to a drastic rise in $\delta^{15} \mathrm{~N}$, which is probably associated with a change in the preference of prey type, from crustaceans in young squid in favour of fish in larger individuals. However, the correlation of prey type with size is less evident in cuttlefish with a more opportunistic food regime that includes crustaceans (such as crabs) in adults (Blanc et al., 1998). These observations are also consistent with a study that demonstrated that the dietary pathway contributes to more than $70 \%$ of inorganic $\mathrm{Hg}$ bioaccumulation in the common cuttlefish (Lacoue-Labarthe et al., 2009b). Additionally, in fish of higher trophic levels than 
crustaceans, $\mathrm{Hg}$ is mainly present as methylmercury (MeHg) (Bloom, 1992; Chouvelon et al., 2008). This organic form of $\mathrm{Hg}$ is thought to be very efficiently assimilated and retained by predators (Pierce et al., 2008), resulting in the biomagnification of $\mathrm{Hg}$ along food webs. These properties of $\mathrm{MeHg}$ also explain the higher $\mathrm{Hg}$ concentrations in adult cephalopods at higher trophic levels. Nevertheless, this association between contamination and age/size remains controversial in octopus (Barghigiani et al., 1991; Raimundo et al., 2004; Raimundo et al., 2010c; Seixas et al., 2005) and sub-adult and adult cuttlefish from the coast of Portugal (Raimundo et al., 2014), in which no relationship between $\mathrm{Hg}$ concentration and size has been found. Moreover, benthic cephalopods generally display significantly higher Hg concentrations than pelagic cephalopods (Bustamante et al., 2006b and Figure 2B). This suggests that processes other than trophic exposure contribute to $\mathrm{Hg}$ bioaccumulation in cephalopods. The transfer of methylated $\mathrm{Hg}$ in sediment and accumulation via the skin and gills of benthic and burying species could explain why these species generally display higher $\mathrm{Hg}$ concentrations than pelagic cephalopods. Certainly, the toxicokinetics of $\mathrm{Hg}$ bioaccumulation, considering both inorganic and organic forms and different sources (sediment, food or water), remains to be clarified, in order to understand differences in $\mathrm{Hg}$ levels observed in the field.

These observations underlie the potential predominance of this trophic source as the contamination pathway, however, experimental studies have highlighted that its relative contribution in metal uptake is trace element-dependent. As mentioned above, toxicokinetic data and application of biodynamic models to estimate the relative contribution of the different pathways of exposure (Landrum et al., 1992; Thomann, 1981) has allowed for determination of the major trophic pathways that contribute to $\mathrm{Cd}, \mathrm{Co}$, inorganic $\mathrm{Hg}$ and $\mathrm{Zn}$ accumulation in squid and cuttlefish fed with fish larvae and brine shrimp, respectively (Bustamante et al., 2002b; Koyama et al., 2000; Lacoue-Labarthe et al., 2009b). Nevertheless, the assimilation of trace elements could be affected by: (1) the prey type, as the proportion of accessible trace elements in the prey may vary (Pouil et al., 2016); (2) the ontogenic stage, as the digestive gland of juveniles is not fully functional compared to adults (Nixon and Mangold, 1998; Yim and Boucaud-Camou, 1980); and (3) environmental conditions, such as temperature or acidity, that may affect the physicochemical forms of trace elements and the metabolism of cephalopods. Each of these factors will, in turn, affect the assimilation efficiency of trace elements by individuals.

In contrast to the elements mainly accumulated from the food pathway, diet only appears to be a minor contributor for Ag compared to direct absorption of waterborne elements (Bustamante et al., 2004). Furthermore, the biological half-life of this element is relatively short in cephalopods. The consequence of the water pathway being the main contributor for $\mathrm{Ag}$ accumulation, combined with its elevated depuration rate, is that $\mathrm{Ag}$ concentrations in the common cuttlefish fluctuate according to environmental contamination conditions during its life cycle. The highest Ag concentrations have been reported to occur in juveniles occupying the coastal nursery grounds, whereas the lowest 
concentrations were found in offshore overwintering individuals (Miramand et al., 2006). The tissues that are in direct contact with seawater, such as the gills and skin, are considered to be the main sites of metal absorption. Indeed, following exposure to dissolved ${ }^{110 \mathrm{~m}} \mathrm{Ag}$, the gills of S. officinalis contained $25 \%$ of the radiotracer content of the whole body, which decreased to $3 \%$ after 6 days in clean water conditions due to its depuration and transfer to other tissues, especially the digestive gland (Bustamante et al., 2004). At the same time, the fraction of Ag in the digestive gland increased from 5 to $61 \%$, implying very efficient translocation of $\mathrm{Ag}$ from interface tissues (e.g., gills and epithelium) to this organ for detoxification and storage. Furthermore, it is noteworthy that the experimentallydetermined biological Ag half-life does not exceed 2 weeks (Bustamante et al., 2004), suggesting the effective elimination of the metal. This corroborates the decreased Ag concentration recorded in wild animals when their exposure to dissolved metals is reduced during their offshore wintering migration (Miramand et al., 2006).

The dominance of the trophic pathway for the accumulation of trace elements, such as $\mathrm{Cd}$ or $\mathrm{Zn}$, do not exclude the significant uptake of dissolved trace elements in seawater (Lacoue-Labarthe et al., 2011; Le Pabic et al., 2015b). Thus, an embryo surrounded by a protective capsule could accumulate dissolved metals that can pass through the eggshell during egg development (for review LacoueLabarthe et al., 2016), inducing high exposure to an environmental contaminant. Moreover, the bioaccumulation efficiency from this uptake route could be affected by environmental factors. The salinity, and also water $\mathrm{pH}$, is known to vary in coastal areas, and are expected to decrease due to climate change (Borges and Frankignoulle, 1999; Caldeira and Wickett, 2005), which can influence chemical speciation, and therefore, the bioavailability of metals (often expressed as the free form fraction) (Millero et al., 2009; Stockdale et al., 2016). Moreover, changes to the metabolism of cephalopods induced by variations in temperature, salinity or hypercarbia affect their physiology (i.e., ionoregulation), and thus, the metal bioaccumulation capacity (Lacoue-Labarthe et al., 2012; LacoueLabarthe et al., 2009a; Lacoue-Labarthe et al., 2011).

The sediment pathway concerns only nectobenthic and benthic species, such as octopus, cuttlefish or sepiolids that display burying behaviours in sand or mud (Poirier et al., 2004). Nevertheless, experimental data has demonstrated that the contribution of contaminated sediment as a source of $\mathrm{Cd}$, Co and $\mathrm{Zn}$ in cephalopod tissues is low (Bustamante et al., 2004; Bustamante et al., 2002b). However, as discussed above, the bioaccumulation of organic $\mathrm{Hg}$, methylated by microorganisms on the seafloor, could significantly contribute to the contamination of cephalopod nectobenthic and benthic species (Bustamante et al., 2006b). To date, no quantitative data are available on this transfer pathway, preventing evaluation of its contribution to whole-body metal concentrations.

The final bioaccumulation pathway, which must be noted due to its potential for causing contamination during early life stages, is maternal transfer. By monitoring the $\mathrm{Cu}$ content of egg 
compartments during development, Decleir et al. (1970) showed progressive transfer of this metal from the yolk to the embryo, suggesting that the supply of this essential trace element for the developing organism is derived from an initial pool of $\mathrm{Cu}$ that is incorporated into the vitelline reserve. The hypothesis of maternal transfer of essential elements is also supported by the presence of higher concentrations of $\mathrm{Cu}, \mathrm{Fe}, \mathrm{Mn}$ and $\mathrm{Zn}$ compared to those of non-essential elements (e.g., $\mathrm{Ag}, \mathrm{Cd}$ and $\mathrm{Pb}$ ) recorded in the eggs of wild S. officinalis (Miramand et al., 2006; Rosa et al., 2015; Villanueva and Bustamante, 2006). The transfer of essential metals from the female to its offspring has been demonstrated experimentaly using radiotracers, showing that ${ }^{75} \mathrm{Se}$ and ${ }^{65} \mathrm{Zn}$ initially assimilated from radiolabelled food by female common cuttlefish were subsequently transferred to the embryos via incorporation in the vitellus (Lacoue-Labarthe et al., 2008b). Interestingly, this maternal transfer is not restricted to metabolically essential trace elements, as ${ }^{110 \mathrm{~m}} \mathrm{Ag}$ has been also found in cuttlefish eggs under the same conditions. In the freshly laid eggs, Ag was found to be equally distributed between the eggshell and vitellus, and was also detected in newly hatched juveniles (Bustamante et al., 2004; Lacoue-Labarthe et al., 2008a). Similarly, As is also likely to be maternally transferred, considering the high concentrations recorded in both the gonads of females (Bustamante et al., 2008; Kojadinovic et al., 2011) and in hatchlings compared to the concentration recorded in juveniles (Le Pabic et al., 2015b). However, to the best of our knowledge, this transfer has not been demonstrated experimentally.

Considering these pathways, the taxonomy, ontogenic stage, geographical area, life history strategy and traits, including the diet and trophic position, all appear to drive the concentration of metals recorded in cephalopods. A combination of both experimental and field studies needs to be considered to explain the importance of these different factors. The toxicokinetic approach (e.g., the use of radiotracers allowing at working at environmental concentrations) involves the use of biokinetic models in order to investigate bioaccumulation processes, including the pathways and effects of biotic and abiotic factors, using the same metal concentrations found in seawater. Determining the concentration of metals in wild specimens remains essential for validating these predictive models and assessing large-scale variations at the population or community levels. The high capacity of cephalopods to concentrate metals raises the question of the detoxification strategy evolved by these organisms to avoid negative impacts of contaminants on individuals and the population. This assumes highly efficient storage of metals by these organisms through unique mechanisms at the tissue and subcellular levels, in order to retain these trace elements in a non-metabolically-available form, thereby limiting their toxicity.

\section{Tissue distribution}


The digestive gland of cephalopods is a complex and polyvalent organ, performing various digestive and excretory functions (Boucaud-Camou and Yim, 1980; Boucher-Rodoni et al., 1987). It is also considered to be the major storage, and consequently, key detoxifying organ, as evidenced by numerous studies highlighting its ability to concentrate trace elements (Bustamante et al., 2003; Bustamante et al., 1998b; Bustamante et al., 2000; Decleir et al., 1978; Miramand and Bentley, 1992; Raimundo et al., 2005; Smith et al., 1984; Ueda et al., 1985), except Hg (inorganic and organic) and As, for which the digestive gland contributes less to the total body burden (Bustamante et al., 2008; Bustamante et al., 2006b; Kojadinovic et al., 2011). Miramand and Bentley (1992) measured the concentration of 11 metals in the digestive gland, branchial hearts, kidney and cuttlebone of two nectobenthic species of cephalopods from the English Channel, the common cuttlefish S. officinalis and the curled octopus Eledone cirrhosa. Although the digestive gland represents only 6 to $10 \%$ of the whole animal tissue, it contains $>80 \%$ of the total body burden of $\mathrm{Ag}, \mathrm{Cd}$ and $\mathrm{Co}$, and 40 to $80 \%$ of the other measured elements. More recently, Raimundo et al. (2010b) also highlighted the key storage role of the digestive gland in Octopus vulgaris from the Portuguese coast. The concentrations of $\mathrm{Cd}$, $\mathrm{Cu}, \mathrm{Pb}$ and $\mathrm{Zn}$ were found to be three or four orders of magnitude higher in the digestive gland when compared to the gills, kidney and gonads. The unique organotropism of trace elements of this organ has raised the question of the role of the digestive gland in terms of the accumulation and detoxification of trace elements, which are stored in a non-toxic form. These observations are supported by evidence of trace elements transfer, monitored using gamma emitting radiotracers (e.g., ${ }^{110 \mathrm{~m}} \mathrm{Ag},{ }^{109} \mathrm{Cd},{ }^{57} \mathrm{Co}$ and ${ }^{65} \mathrm{Zn}$ ), from interface tissues (skin and gills) that are directly exposed to the waterborne contamination to the digestive gland in S. officinalis (Bustamante, 1998; Bustamante et al., 2004; Bustamante et al., 2002b). Nevertheless, this mechanism of trace element accumulation is not without adverse consequences, as DNA damage in O. vulgaris, such as broken strands, were found to be higher in the digestive gland compared to the other tissues analysed (Raimundo et al., 2010a), meaning that these potential detoxification mechanisms could be bypassed.

Branchial hearts are another predominant site for the storage of metallic elements such as Co (including ${ }^{60} \mathrm{Co}$ ), $\mathrm{Ni}$ and $\mathrm{V}$, and of transuranic elements such as ${ }^{241} \mathrm{Am}$ and ${ }^{239-240} \mathrm{Pu}$ (Guary and Fowler, 1982; Guary et al., 1981; Miramand and Bentley, 1992; Miramand and Guary, 1980, 1981; Nakahara et al., 1982; Ueda et al., 1985), even more than the digestive gland itself. This is particularly the case for $\mathrm{Co}$, the concentration of which has been found to be about three-times higher in branchial hearts than in the digestive gland of $O$. vulgaris (Ueda et al., 1979). The branchial hearts were found to contain up to $50 \%$ of the whole-body radioactivity in $O$. vulgaris exposed to ${ }^{60} \mathrm{Co}$, even though this organ only represents $0.2 \%$ of the total body weight of the octopus (Nakahara et al., 1982). Other trace elements, such as $\mathrm{Cd}$ and $\mathrm{Cu}$, are also concentrated in the branchial hearts, but to a significantly less extent than the digestive gland (Miramand and Bentley, 1992). Bustamante et al. (2002) showed that $\mathrm{Cd}$ in the branchial heart was derived from waterborne $\mathrm{Cd}$, whereas $\mathrm{Cd}$ from food was completely 
contained within the digestive gland. The involvement of the branchial hearts in the hemocyanin metabolism of coleoid cephalopods is consistent with the presence of $\mathrm{Cu}$ within this tissue (Beuerlein et al., 1998; Mangold, 1989), Cu being the respiratory pigment of hemocyanin. Moreover, following exposure to dissolved ${ }^{109} \mathrm{Cd}$ and ${ }^{65} \mathrm{Zn}$ radiotracers, the branchial hearts and appendages of S. officinalis exhibit high Cd levels following its transfer from the skin, gills and muscles (Bustamante et al., 2002). Considering the short biological half-life of dissolved $\mathrm{Cd}$ accumulated in the whole organism (approximately 2 months), and the physiological circulatory and excretory functions of the haemolymph, the waterborne-derived $\mathrm{Cd}$ transported by the blood appears to be excreted through the branchial hearts and appendages. A similar mechanism of transfer was also observed for ${ }^{60} \mathrm{Co}$ in $O$. vulgaris (Nakahara et al., 1979).

While the highest $\mathrm{Hg}$ concentrations have been recorded in the digestive gland, $\mathrm{Hg}$ was found to be mainly stored in the muscle in terms of body burden distribution. Bustamante et al. (2006b) reported that 70 to $90 \%$ of the total $\mathrm{Hg}$ body burden was stored in the muscular tissue of different cephalopod species collected from the North-east Atlantic Ocean. More than $80 \%$ of dissolved inorganic ${ }^{203} \mathrm{Hg}$ accumulated in juvenile cuttlefish was also found to be stored in muscle (Lacoue-Labarthe et al., 2009b). This unique distribution could be firstly explained by the fact that these tissues represent more than $70 \%$ of the total body weight. Secondly, in the digestive gland, the main fraction of $\mathrm{Hg}$ is the inorganic form, in contrast to the large proportion of organic mercury $(\mathrm{MeHg})$ found in muscle tissue. This suggests that demethylation of organic $\mathrm{Hg}$ could occur in this organ, and/or that $\mathrm{MeHg}$ is translocated from the digestive gland to muscle due to its high affinity for the sulphydryl groups of muscular proteins rather than fat tissue (Bloom, 1992; Bustamante et al., 2006b). However, the muscle storage capacity appears to be limited in most contaminated octopuses collected along the Portuguese coast, in which $\mathrm{Hg}$ and $\mathrm{MeHg}$ concentrations reached a threshold, whereas $\mathrm{Hg}$ concentrations were increased in the digestive gland (Raimundo et al., 2010c).

In summary, trace elements are found to be highly concentrated in specific cephalopod tissues. Although the toxicity of contaminants in cephalopods is relatively unknown, the absence of acute effects caused by high metal concentrations, as reported previously, imply that biochemical processes occur at both the tissue and cellular levels to store these elements in non-chemically active forms, thereby limiting their toxic interactions with molecular and cellular compounds, or to a lesser extent, allowing their elimination.

\section{Mechanisms of trace element detoxification at the cellular level}

\subsection{Metal-rich deposits in branchial hearts}

As mentioned above, metals such as $\mathrm{Co}, \mathrm{Cu}, \mathrm{V}$ and transuranic elements are abundantly or mainly located in the branchial hearts. This tissue is mainly composed of ovoid cells, also called rhogocytes or 
polyhedral cells, hemocytes derived from circulating blood, and the adhesive hemocytes in the wall of the branchial hearts. Rhogocytes are involved in haemolymph detoxification by eliminating endogenous or exogenous substances, such as ferritin, colloidal gold or bacteria (Beuerlein et al., 2002; Beuerlein and Schipp, 1998). These rhogocytes can contain high amounts of numerous pigmented granules composed of metabolic intracellular waste and Fe (III). These structures, called adenochroms (Miramand and Guary, 1981), could be considered to be natural bonders for different metals such as Co or V and transuranic elements, and are believed to participate in their detoxification (Figure 3). Finally, rhogocytes are thought to be involved in hemocyanin metabolism (Beuerlein et al., 2004; Ruth et al., 1999), explaining the elevated $\mathrm{Cu}$ levels in branchial hearts.

\subsection{Metal-rich deposits in digestive gland cells}

\subsubsection{Histological insights}

Several studies have attempted to unravel the physiological mechanisms involved in the storage capacity of the digestive gland, especially through the use of histological investigations.

Histological observations of the digestive gland structure of cuttlefish revealed that it is composed of numerous tubules with a clearly-defined lumen (Boucaud-Camou and Yim, 1980). As first described by Cuénot (1907), three different cell types make up the digestive gland, including basal cells, digestive cells and excretory cells (Figure 3). Basal cells, with their typical triangular shape, are situated between the basal lamina of tubules and the digestive cells. The numerous digestive cells, derived from the differentiation of basal cells, are involved in intracellular digestion, containing vacuoles that are generally coloured pale yellow to light brown. These vacuoles were originally named "boules" by Cuénot (1907), and probably contain residual peptides and lipids from intracellular digestion (Boucaud-Camou and Yim, 1980). The content of these vacuoles is excreted into the lumen of the digestive tubules, suggesting that these digestive cells potentially play a role in the excretion of digestive waste as well as contaminants. These digestive cells can differentiate into excretory cells, which are more rarely observed according to Costa et al. (2014), located close to the apical lamina, and mainly composed of a single large vacuole. These excretory cells are thought to play an important role in the excretion of salts.

Histological analyses by Martoja and Marcaillou (1993) showed the presence of metal-rich spherules in the basal cells of the digestive gland of S. officinalis. In these spherules, they noted the presence of $\mathrm{Cu}$ and $\mathrm{S}$ in particularly high amounts, and other numerous elements in the descending order: $\mathrm{Zn}>\mathrm{Ag}$ and $\mathrm{Ca}>\mathrm{Mg}>\mathrm{Sr}$. Based on several indirect analyses, these authors hypothesised that these spherules contain metallothionein-like proteins (MTLP; cysteine-rich proteins to which several metals have a high affinity) as a trace element ligand embedded within a polymer matrix. Surprisingly they were 
unable to find an association between Cd, well-known for its high affinity to MTLP, and such spherules, calling into question their composition and role in trapping metals.

More recently, Costa et al. (2014) provided a more detailed structural and chemical description of the basal cells in the digestive gland, strengthening previous results from Martoja and Marcaillou (1993) in the same species. Thus, calcic spherules rich in $\mathrm{Cu}$ and $\mathrm{Pb}$ (the latter in a dichromate form) were identified in the basal cells. They were found to be composed of a complex organic protein matrix, originating from an extension of the rough endoplasmic reticulum, also suggested to contain MTLP. Therefore, it is suggested that trace elements initially bound to soluble proteins were trapped in solid proteo-mineral structures. Therefore, the basal cells containing these spherules are likely to be involved in trace element detoxification, allowing their storage in a non-chemically-active form. It is noteworthy that these typical metal-rich structures have not been consistently observed in the digestive gland of cephalopods. Neither Boucaud-Camou and Boucher-Rodoni (1983) nor Bustamante (1998) observed these granule-like structures in the digestive gland cells of S. officinalis or Todarodes sagittatus, respectively. However, the variety of histochemical protocols utilised could explain these contrasting observations, such as the use of unsuitable fixatives, as suggested by Martoja and Marcaillou (1993).

Another plausible role for the basal cells in the maintenance of $\mathrm{Cu}$ homeostasis has been proposed. Martoja and Marcaillou (1993) highlighted structural similarities in shape and cytological properties between the basal cells (previously called "replacement" or "pyramid" cells) of the digestive glands of S. officinalis and Nautilus pompilius, involved in hemocyanin synthesis (Ruth et al., 1999; Ruth et al., 1988). This particular triangular shape is found in the digestive gland cells of both species, and the rough endoplasmic reticulum is also highly developed in both cases, and extended in these spherule shapes. Thus, a particular function of this special cell type in $\mathrm{Cu}$ regulation cannot be excluded, considering the large amount of $\mathrm{Cu}$ found in the spherules.

Finally, the digestive cells contain two other structures which can participate in trace element detoxification: (1) the "boules" structures, corresponding to typical vacuoles (e.g., heterolysosomes), probably involved in intracellular digestion and enzyme secretion (Boucaud-Camou, 1972); and (2) the brown bodies, which are large vacuoles containing cellular debris, thought to have an excretory role, previously observed to contain Fe deposits in S. officinalis (Costa et al., 2014). As lysosomes are known to accumulate trace elements from the cytosol, considered to be a method of their elimination in invertebrates (Dallinger, 1993; Marigomez et al., 1996; Moore, 1990), a similar role for the "boules" of digestive cells can be expected. The subcellular distribution of trace elements in the digestive gland of S. officinalis showed that, among others, 44, 30 and $31 \%$ of accumulated $\mathrm{Ag}, \mathrm{Fe}$ and $\mathrm{Zn}$, respectively, were located within the lysosomal fraction (Tanaka et al., 1983). Similarly, Bustamante et al. (2006a) noticed that more than $75 \%$ of the Ag burden was in the lysosome and 
mitochondrial fractions. Additionally, Raimundo et al. (2008) showed a positive correlation between metals contained in lysosomes in $O$. vulgaris and the total quantity of metals found in the whole digestive gland. Interestingly, the structure of the digestive gland in Loliginidae is quite different from the other coleoid cephalopods (at least from cuttlefish and ommastrephid squid), as their lysosomal system is comparatively less developed, also lacking the "boules" structures (Boucaud-Camou and Boucher-Rodoni, 1983). Thus, it is expected that such characteristics could limit the metal detoxification/storage performance in Loliginidae, considering that they often exhibit a lower metal concentration compared to other cephalopods from the same area. For instance, Bustamante et al. (2002a) related the lowest Cd bioaccumulation capacity of loliginid squid (Figure 2A) to the absence of boules.

\subsubsection{Subcellular partitioning}

Overall, only few studies have investigated the subcellular distribution of metals in the digestive gland (Bustamante et al., 2006a; Bustamante et al., 2002a; Craig and Overnell, 2003; Finger and Smith, 1987; Raimundo et al., 2008, 2010d; Rocca, 1969; Tanaka et al., 1983), most of which have considered only the insoluble (including organelles, nuclei and cellular debris) and the soluble (cytosol) subcellular fractions, separated by successive centrifugation steps. Only few metals, $\mathrm{Cd}, \mathrm{Cu}$ and $\mathrm{Zn}$, have been extensively studied in these works, with $\mathrm{Ag}$ investigated to a lesser extent, for which the subcellular distribution varies considerably between species.

In the digestive gland of the common cuttlefish S. officinalis, $\mathrm{Cd}$, $\mathrm{Co}$ and $\mathrm{Cu}$ are mostly found in the cytosol, meaning that these metals are associated with soluble proteins, whereas $\mathrm{Ag}, \mathrm{Fe}, \mathrm{Mn}, \mathrm{Pb}$ and $\mathrm{Zn}$ are mainly found in the organelle fraction, suggesting that these metals could be bound to or sequestrated within cell structures (Bustamante et al., 2006a). These results are consistent with observations in the digestive gland of other cephalopod species, at least with respect to $\mathrm{Cd}$, which has been shown to be mainly (50 to 96\%) distributed in the cytosolic fraction of the digestive gland cells of E. cirrhosa, S. officinalis, S. orbignyana, S. elegans, Illex coindetti, N. gouldi, T. sagittatus, O. vulgaris and L. vulgaris, in ascending order (Bustamante et al., 2002a; Finger and Smith, 1987; Raimundo et al., 2008, 2010d). In contrast to this, Cd was mainly found to be associated with the insoluble fraction, composed of organelles, nuclei and cell debris, in the Japanese squid T. pacificus (Tanaka et al., 1983). This might be explained by: (1) varying contributions of the trace element uptake pathways (waterborne, sediment and trophic routes) among species, and/or (2) differences in the trace element concentrations in the digestive gland (Bustamante et al., 2006a; Bustamante et al., 2002a). According to a study on $O$. ocellatus, differences in the contribution of exposure routes does not appear to have an effect on subcellular metal distribution (Koyagani et al., 1982). However, Bustamante et al. (2002a) showed that when the Cd concentration in the digestive gland of 
cephalopods increased, this metal was continuously transferred from the soluble to the insoluble compartment. Additionally, the subcellular partitioning of $\mathrm{Cd}$ investigated in seven cephalopod species displayed a large range of total $\mathrm{Cd}$ levels in the digestive gland. The results highlighted a negative correlation between the percentage of $\mathrm{Cd}$ found in the soluble fraction and the $\mathrm{Cd}$ concentration. This suggests that a concentration threshold probably exists, as $\mathrm{Cd}$ is mostly accumulated within insoluble parts of digestive gland cells. The literature reports the precipitation of trace elements into insoluble granules in various invertebrates as a common trace element storage and detoxification mechanism (e.g. George et al., 1982). Thus, the subcellular distribution strengthened the hypothesised role of the basal cell spherules, described above, in metal detoxification. From these observations, it is difficult to find one common mechanism that can be applied to every cephalopod species. Additionally, the observed subcellular distribution cannot be explained by the biological role of specific trace elements, as both essential and non-essential elements are found in the soluble and insoluble fractions in varying proportions. However, it is noteworthy that subcellular fractioning is an accurate procedure from an experimental point of view, as it requires a high degree of precision to ensure that the fraction obtained corresponds to the fraction required. Consequently, it is possible to observe an overlap between several fractions, and their identification using techniques such as enzyme activity measurements or ultrastructural observations, is not always performed.

The relationship between non-essential trace element concentrations in the digestive gland and those found in organelles are also of concern for the toxicological risk to the organism. Regarding $\mathrm{Cd}$ and $\mathrm{Pb}$ levels in the digestive gland of wild $O$. vulgaris, increased metal concentrations are associated with enhanced $\mathrm{Cd}$ and $\mathrm{Pb}$ concentrations within the mitochondria and nuclei, respectively (Raimundo et al., 2008). The binding of these metals to key cell structures raises the question of the potential toxic effects of these elements on cellular respiration and nucleus function. Indeed, in the same species, elevated DNA damage has been observed in the digestive gland compared to other tissues (Raimundo et al., 2010a). Nevertheless, DNA damage can be induced by genotoxicants other than trace elements, also known to show high accumulation in this organ. Further studies are required to assess the potential impact of metals on cellular and physiological function, particularly information regarding their toxicology in cephalopods, which is is especially lacking.

Cephalopods are a major component of the diet of numerous predators such as fish, marine mammals and seabirds (Clarke, 1996; Croxall and Prince, 1996; Klages, 1996), therefore, they constitute a potentially important source of trace elements (Bustamante et al., 1998a; Muirhead and Furness, 1988). Evaluation of the trophically available metals (TAM) could be one possible tool to estimate contaminant transfer from cephalopods to predators (Wallace et al., 2003; Wallace and Luoma, 2003). This could be performed by assessing the metals contained in the soluble fraction, suggested to contain the efficiently assimilated metals. Thus, the most concerning data would be for $\mathrm{Cd}$, which seems to be more abundant in the soluble fraction of the digestive gland. This is especially worrying due to the 
deleterious effects induced by this metal in vertebrates (Fleischer et al., 1974). For example, a greyheaded albatross from Kerguelen Islands was found to have ingested $11.2 \mathrm{mg}$ of $\mathrm{Cd}$ per $\mathrm{kg}$ of body weight per week from three squid, which is approximately 500-times higher than the weekly tolerable intake for humans (Bustamante et al., 1998a).

\subsubsection{Metal-binding proteins}

As described above, when trace elements are not bound to organelles, they are often found in the soluble fraction, where they are associated with cytosolic proteins, thereby inhibiting the toxic interactions of metallic ions with sensitive binding sites (proteins, molecules or cell structures). The formation of complexes of trace elements with specific proteins has been subject of several studies in various cephalopods species, including cuttlefish (Bustamante et al., 2006a; Bustamante et al., 2002a; Decleir et al., 1978), squid (Castillo and Maita, 1991; Finger and Smith, 1987; Tanaka et al., 1983), and octopus (Bustamante et al., 2002a; Nakahara et al., 1979; Raimundo et al., 2010b; Raimundo et al., 2008, 2010d; Rocca, 1969; Ueda et al., 1985). The targeted tissues included the digestive gland as the preferential organ for trace element accumulation, in addition to the branchial hearts, branchial gland, kidneys, blood and muscle. As for other studies that have investigated trace element detoxification in cephalopods, only few trace elements are usually targeted, the most common of which are $\mathrm{Cd}, \mathrm{Cu}$ and $\mathrm{Zn}$. Even with these metals, the results obtained vary significantly among species, making it difficult to conclude a single or general rule.

In the digestive gland of the common cuttlefish $S$. officinalis and the Ommastrephes bartrami, Nototodarus gouldi and T. pacificus squid, soluble $\mathrm{Cd}$ is mostly bound to high molecular weight (HMW) proteins (> $70 \mathrm{kDa}$ ) (Bustamante et al., 2006a; Castillo and Maita, 1991; Finger and Smith, 1987; Tanaka et al., 1983), whereas 53\% of Cd in the squid Onychoteuthis borealijaponica is bound to low molecular weight (LMW) proteins (> $3 \mathrm{kDa}$ ) (Castillo and Maita, 1991) (Table 1). Similarly, Raimundo et al. (2010d) also showed a preferential association of Cd to LMW protein complexes in the digestive gland of $O$. vulgaris. Such differences could be explained by: (1) differences in protocol for the chromatographic analysis, in particular, whether not a reducing agent was used (Table 1); (2) inter-specific variations in detoxification processes using soluble proteins; and (3) the contrasting magnitude of metal exposure between the species evaluated. More precisely, when $\mathrm{Cd}$ is present in the digestive gland at low concentrations it is bound to only one type of protein (HMW in squid and cuttlefish, LMW in octopus), whereas two proteins fractions are identified when the total $\mathrm{Cd}$ concentration exceeds $40 \mu \mathrm{g} \cdot \mathrm{g}^{-1}$, regardless of the species (Table 1). As suggested by Raimundo et al. (2010d), the Cd level in the digestive gland drives a transient detoxification strategy, based on the formation of Cd complexes with HMW proteins when Cd levels are low, which changes to binding to 
LMW proteins when the $\mathrm{Cd}$ concentration exceeds a certain threshold. In this case, $\mathrm{Cd}$ could be trapped within insoluble structures, as described above.

Concerning the nature of these metal-binding proteins, several authors have suggest LMW proteins such as MTLP (Bustamante et al., 2002a; Decleir et al., 1978; Finger and Smith, 1987; Raimundo et al., 2010b; Tanaka et al., 1983). Metallothioneins (MTs) are well-known LMW (about 6-7 kDa), heat stable and cysteine-rich proteins. Furthermore, metals like $\mathrm{Ag}, \mathrm{Cd}, \mathrm{Cu}, \mathrm{Hg}$ and $\mathrm{Zn}$ have a high affinity for MTs due to their high thiol group content (Viarengo and Nott, 1993). Thus, MTs are thought to play a key role in the homeostasis of essential metals, in addition to an important role in the trace element tolerance of organisms (Amiard et al., 2006). Indeed, their unique affinity for trace elements gives them the ability to scavenge not only essential, but also non-essential trace elements, with the affinity suggested as follows: $\mathrm{Hg}>\mathrm{Cu}, \mathrm{Ag}, \gg \mathrm{Cd}>\mathrm{Pb}>\mathrm{Zn}>\mathrm{Co}$ (Vasak, 1991). It has been widely demonstrated that exposure of organisms to trace elements could lead to the induction of MTs through Zn-sensitive inhibitor mediation of MT genes (see Amiard et al., 2006). To the best of our knowledge, structural characterisation of MTs from cephalopods has not yet been performed. Nevertheless, several authors have confirmed the presence of proteins of a similar weight that bind trace elements, using MTs from other species (rat, rabbit and horse). It has been shown that proteins with a molecular weight close to that of MTs from other species mainly bind $\mathrm{Cu}$ in Todarodes pacificus (Tanaka et al., 1983) and Sepia officinalis (Bustamante et al., 2006a), bind Cd in Ommastrephes borealijaponica, O. bartrami and T. pacificus squid (Castillo and Maita, 1991; Tanaka et al., 1983), and $\mathrm{Zn}$ in O. bartrami (Castillo and Maita, 1991).

The quantification of MTs in the digestive gland through the measurement of thiol groups has highlighted the wide variation in MT concentrations among cephalopod species, ranging from 700 to $3500 \mu \mathrm{g} . \mathrm{g}^{-1}$ wet weight (Bustamante et al., 2002a; Raimundo et al., 2010b). However, these levels are comparable to those found in other molluscs, such as the mussel Mytilus galloprovincialis (Pavičić et al., 1993) and gastropod Littorina littorea (Bebianno et al., 1992). Interestingly, the lowest levels of $\mathrm{Cd}$ (and also the highest percentage of soluble $\mathrm{Cd}$ ) were found to be associated with the highest levels of MTs (Bustamante et al., 2002a), suggesting: (1) MTs are probably not the main pathway of detoxification for $\mathrm{Cd}$ in cephalopods; and (2) other detoxification mechanisms occur beyond a particular concentration threshold, potentially involving heavier soluble proteins or binding to insoluble structures.

Regarding essential metals, Le Pabic et al. (2015b) demonstrated a positive correlation between the whole organism $\mathrm{Cu}$ and $\mathrm{Zn}$ concentrations and MTs in juvenile cuttlefish, which is consistent with the essential role that MTs may play in the homeostasis of essential trace elements in cephalopods. However, based on several indirect methods, Craig and Overnell (2003) showed there was no evidence of MT involvement in $\mathrm{Cu}$ or $\mathrm{Zn}$ regulation in the eggs, hatchlings or adult tissues (digestive gland, 
muscle and eyes) of the veined squid L. forbesi. Nevertheless, taking into account the small amount of lysosomes contained within the digestive gland of Loliginidae, combined with the histological observations that MTLPs are mainly located within lysosomes (Martoja and Marcaillou, 1993), these observations may be in accordance with those previously reported. This raises the question of the relative importance of MTs in the homeostasis of essential elements in cephalopods, and further investigations are required in order to elucidate their role.

Additionally, Castillo and Maita (1991) purified a protein fraction of approximately $16 \mathrm{kDa}$ from the digestive gland cells of the squid $O$. bartrami. They demonstrated the occurrence of three differently charged proteins that bind $\mathrm{Cd}, \mathrm{Cu}$ and $\mathrm{Zn}$ within a similar weight fraction. Amino acid characterisation of these proteins found that the cysteine content appeared to be lower than the detection limit, suggesting that this fraction contained only a very low amount of MTs. Nevertheless, these authors highlighted the high content of aspartic and glutamic acids in these proteins, which can also bind trace elements (Viarengo et al., 1988). When combined, aspartic and glutamic acids constitute 21-29\% of the total molar ratio of these proteins, which is comparable to the high cysteine content (25-30\%) found in MTs. The authors suggested that trace elements must be bound to dicarboxylic amino acids instead of thiolates.

\section{Conclusion}

This paper attempted to review the existing knowledge regarding the high capacity of cephalopods to concentrate metallic trace elements in their tissues, to assist in unravelling the physiological mechanisms involved in metal homeostasis. It also highlighted the lack of knowledge in this area, which requires investigation in order to obtain an overall understanding of the ecotoxicology of these exceptional organisms. It appears that the detoxification mechanisms include both dynamic and transient processes, allowing the storage and/or elimination of metals depending on the exposure conditions. However, such mechanisms need to be further explored, taking into account the physiology, particularly the digestive physiology, and the life traits of each species, in order to explain the differences in bioaccumulation capacity observed among cephalopod species. In addition, the trophically available metals (TAM) fractions that could be transferred from cephalopods to predators (Wallace et al., 2003; Wallace and Luoma, 2003) might be driven by the detoxification / storage strategies in the prey. As cephalopods are a major component of the diet of numerous predators such as fish, marine mammals and seabirds (Clarke, 1996; Croxall and Prince, 1996; Klages, 1996), unravelling their metal metabolism is therefore essential for perceiving their key role in trace elements transfer and/or biomagnification in marine food web (Bustamante et al., 1998a; Muirhead and Furness, 1988). 
Furthermore, little is known about the toxicological risks of such bioaccumulation capacities on the physiological and ecological performance and fitness of cephalopods. As recently shown, the cephalopod population is increasing globally, despite growing anthropogenic pressure and changes in climatic conditions occurring in oceans (Doubleday et al., 2016), suggesting an apparent tolerance to marine environment contamination. Nevertheless, considering the growing interest in cephalopods by fisheries as food resources, and their key role in marine trophic webs, this work highlights the need to gain a better understanding of the ecotoxicology of metals, and more broadly, of others pollutants in cephalopods. Further works would have to combine physiological, toxicological and biogeographical approaches to address the gaps of knowledge reported in this paper.

\section{Acknowledgments}

This paper is a contribution of the TREEFACIL project (Transfert des éléments traces sous l'effet de l'acidification des océans chez les céphalopodes) supported by the French INSU/EC2CO ECODYN program. Virginie Penicaud was supported by a PhD grant from the French Ministry of Education and Research and from the University of La Rochelle. 
Table 1. Concentrations ( $\mu \mathrm{g} . \mathrm{g}-1 \mathrm{dw}$ ) and proportion in the cytosol (\%) of Cd in the digestive gland of 4 cephalopod species as well as the molecular weight of proteins associated with $\mathrm{Cd}$. Main and minor peaks refer to the fractions to which associated $\mathrm{Cd}$ concentrations were the highest and lowest (but detectable), respectively, following chromatographic analysis.

\begin{tabular}{|c|c|c|c|c|c|c|c|}
\hline Species & {$[\mathrm{Cd}] \mu \mathrm{g} \cdot \mathrm{g}^{-1} \mathrm{dw}$} & \% in cytosol & $\begin{array}{l}\text { Main } \\
\text { peak }\end{array}$ & $\begin{array}{l}\text { Minor } \\
\text { peak }\end{array}$ & Protein weight $(\mathrm{kDa})$ & Reducing agent & Reference \\
\hline Nototodarus gouldi & $\begin{array}{l}10-30 \\
40-80\end{array}$ & $70 \%$ & $\begin{array}{l}\text { HMW } \\
\text { HMW }\end{array}$ & IMW & $\begin{array}{c}70 \mathrm{kDa} \\
>70 \mathrm{kDa}+20 \mathrm{kDa}\end{array}$ & Mercaptoethanol $^{\mathrm{a}}$ & Finger and Smith (1987) \\
\hline Ommastrephes bartrami & 211 & NA & $\begin{array}{l}\text { IMW } \\
\text { HMW }\end{array}$ & LMW & $\begin{array}{c}16 \mathrm{kDa}(10-30 \mathrm{kDa}) \\
>70 \mathrm{kDa}\end{array}$ & $\begin{array}{l}\text { Mercaptoethanol } \\
\text { no }\end{array}$ & Castillo and Maita (1991) \\
\hline $\begin{array}{l}\text { Onychoteuthis } \\
\text { borealijaponica }\end{array}$ & NA & NA & LMW & & $3 \mathrm{kDa}$ & Mercaptoethanol & Castillo et al. (1990) \\
\hline Todarodes pacificus & $38-82$ & $30 \%$ & HMW & IMW & $70 \mathrm{kDa}+11-16 \mathrm{kDa}$ & no & Tanaka et al. (1983) \\
\hline Sepia officinalis & 15 & $53 \%$ & HMW & & $70 \mathrm{kDa}$ & no & Bustamante et al. (2006a) \\
\hline Octopus vulgaris & $\begin{array}{c}10-30 \\
57-252\end{array}$ & $93 \%$ & $\begin{array}{l}\text { LMW } \\
\text { LMW }\end{array}$ & HMW & $\begin{array}{c}\text { 6-11 kDa } \\
6-11 \mathrm{kDa}+130-140 \mathrm{kDa}\end{array}$ & $\begin{array}{l}\text { no } \\
\text { no }\end{array}$ & $\begin{array}{l}\text { Raimundo et al. (2010d) } \\
\text { Raimundo et al. (2008) }\end{array}$ \\
\hline
\end{tabular}

HMW: high molecular weight; IMW: intermediate molecular weight; LMW: low molecular weight. NA: not available. 


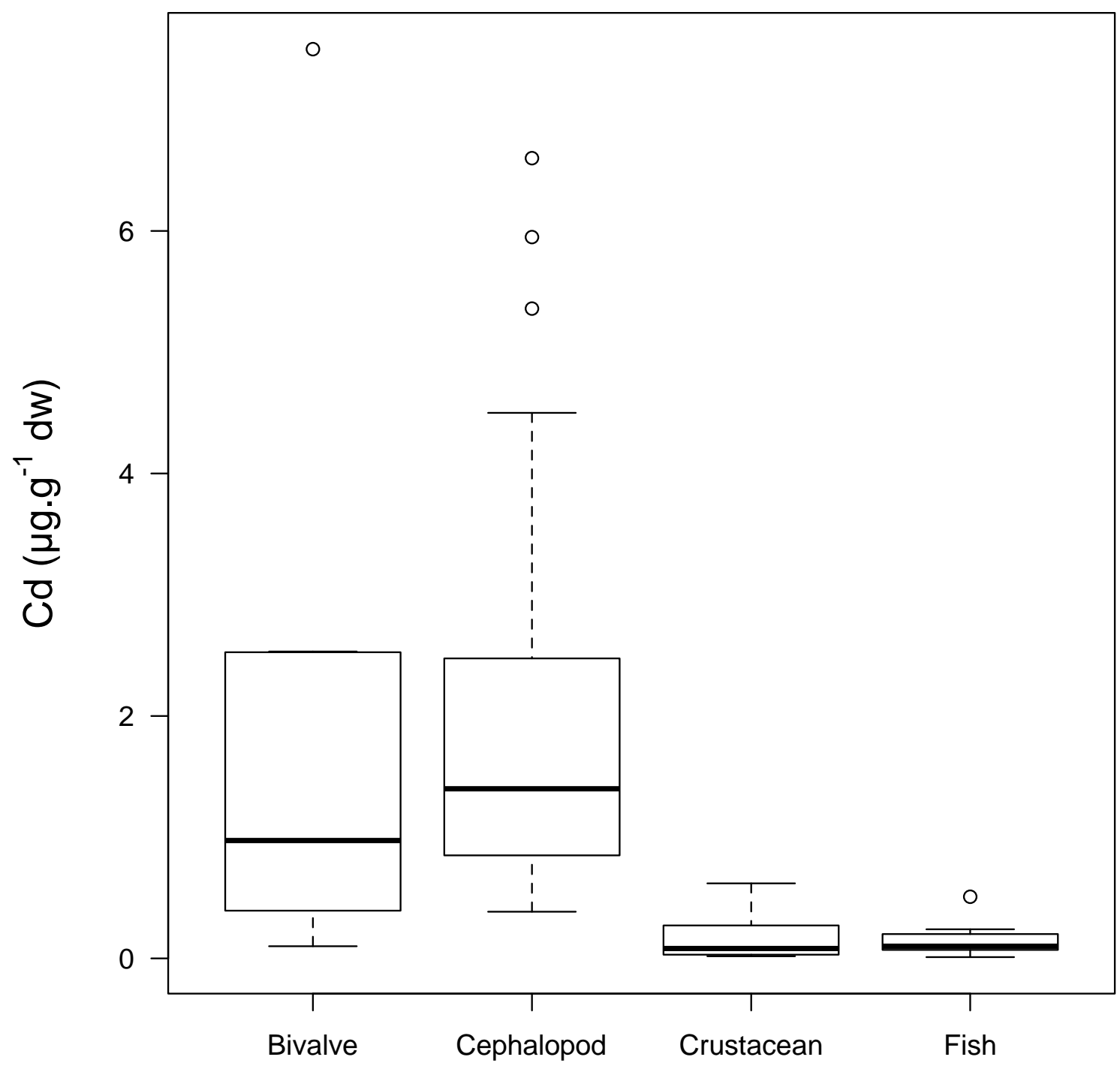

Figure 1. Whole body (or soft parts for Bivalves) concentrations of Cd ( $\mu \mathrm{g} . \mathrm{g}-1$ dry weight) in different order of Fish, in Crustacean Decapods, in different Families of Bivalves and Cephalopods collected in the Bay of Biscay and the English Channel. Please note that these data are not exhaustive and illustrate the capacity of $\mathrm{Cd}$ bioaccumulation of cephalopod compared to others marine organisms. Per: Perciforme; Clup: Clupeiforme; Gad: Gadiforme; Myc: Myctophiforme; Ang: Anguilliforme; Dec: Decapod; Ven: Veneridae; Tel: Tellinidae; Myt: Mytilidae; Ost: Ostreidae; Pec: Pectinidae; Oct: Octopodidae; Sep: Sepiidae; Loli: Loliginidae; Om: Ommastrephidae; His: Histioteuthidae; Cra: Cranchiidae. Data extracted from the literature are detailed in Table S1. 

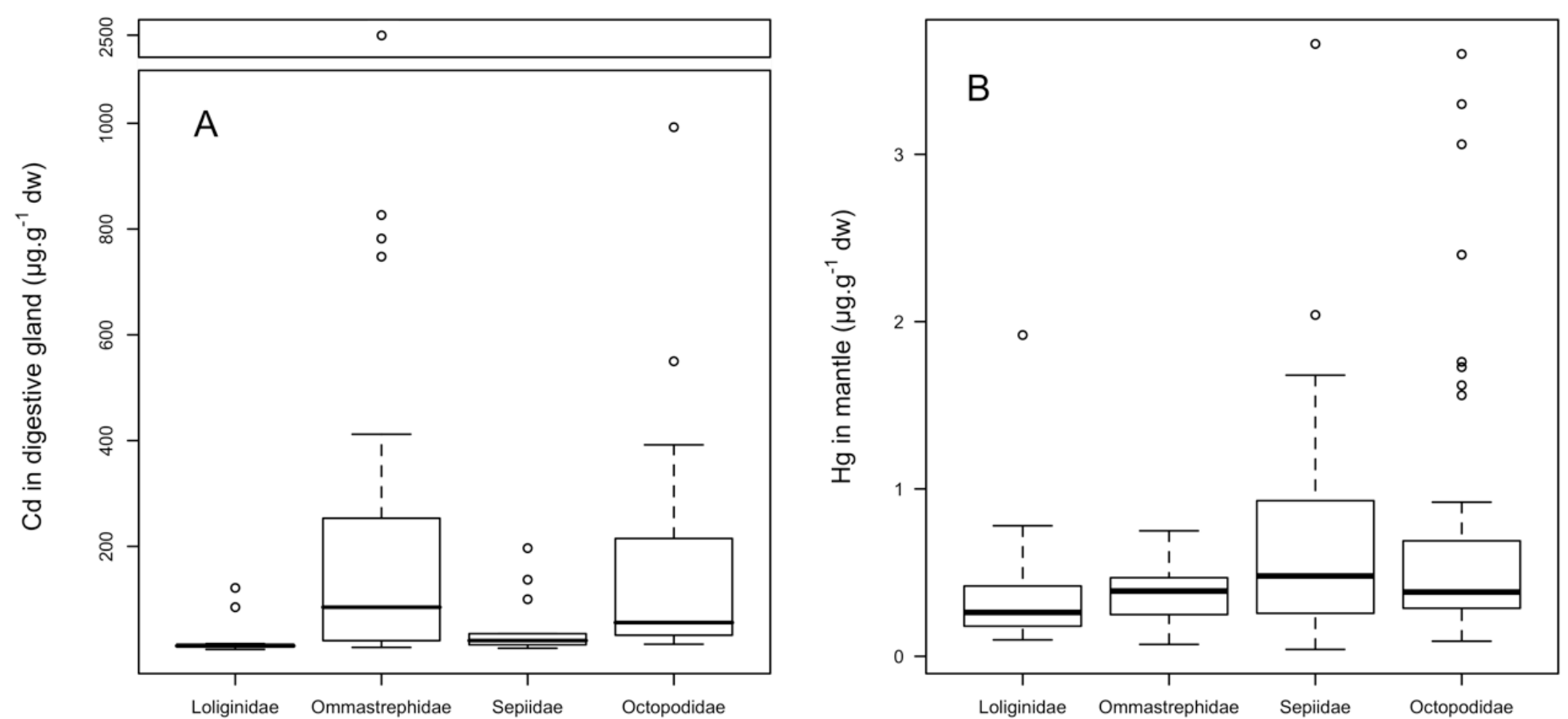

Figure 2. Cd (A) and $\mathrm{Hg}$ (B) concentrations (in $\mu \mathrm{g} . \mathrm{g}^{-1}$ dry weight) in the digestive gland and muscle, respectively, of cephalopods from the main four families (i.e. Loliginidae and Ommastrephidae squids, Sepiidae and Octopodidae) collected worldwide, with taxonomy discrimination. Data extracted from the literature are detailed in Table S2 and S3. 


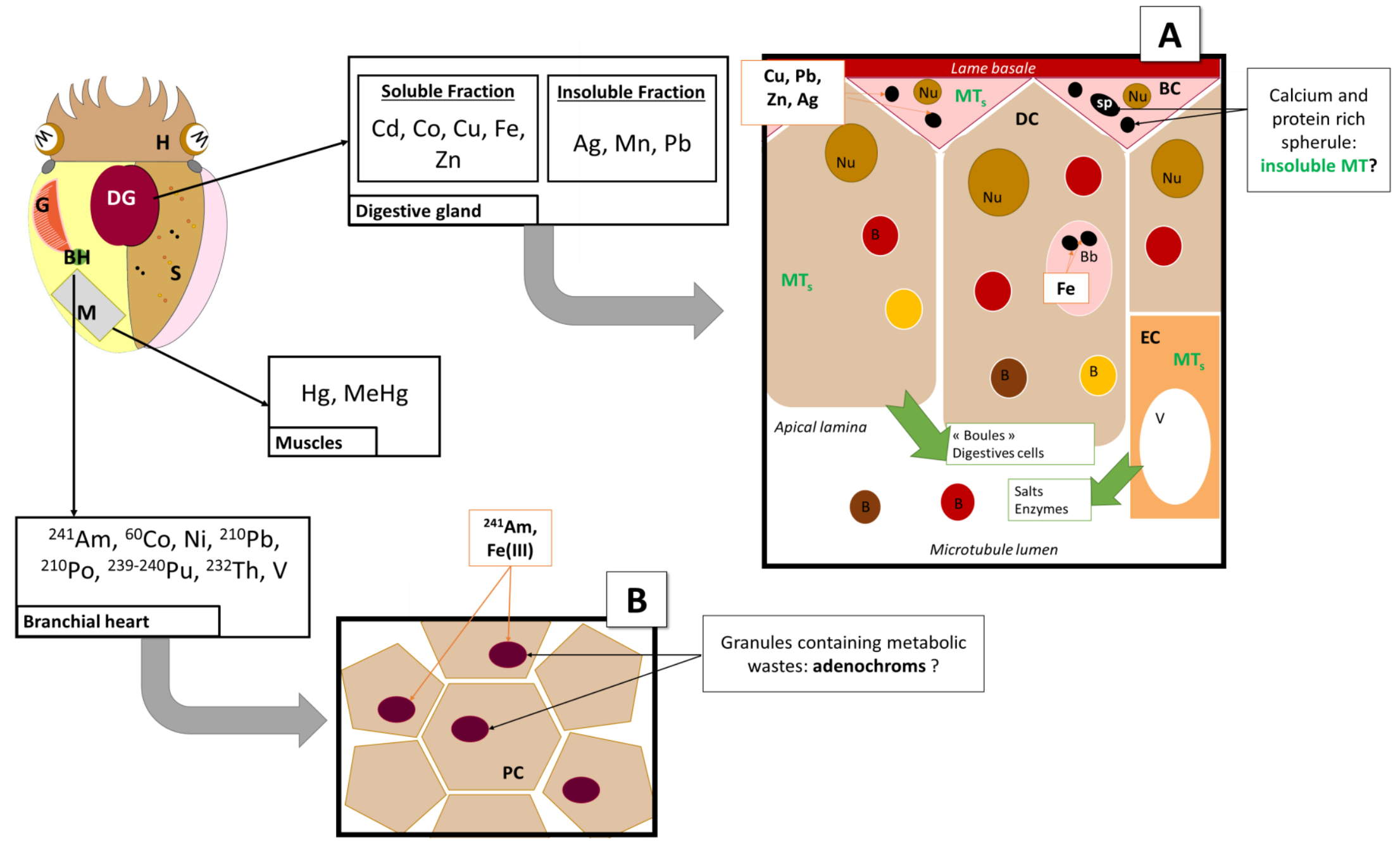

Figure 3. Simplified representation of metal bioaccumulation and organotropism in the common cuttlefish, S. officinalis. (A) Subcellular schematic view of the digestive gland. B: "boules" structures, heterolysosomes; Bb: Brown bodies; BC: Basal cells; DC: Digestive cells; EC: Excretory cells; MTs: Soluble metallothioneins; Nu: Nucleus; V: vacuole. (B) Subcellular schematic view of branchial hearts. PC: Polyhedral cells. 
Amiard, J.C., Amiard-Triquet, C., Barka, S., Pellerin, J., Rainbow, P.S., 2006. Metallothioneins in aquatic invertebrates: their role in metal detoxification and their use as biomarkers. Aquat Toxicol 76, 160-202.

Barghigiani, C., Pellegrini, D., D'Ulivo, A., De Ranieri, S., 1991. Mercury assessment and its relation to selenium levels in edible species of the northern Tyrrhenian Sea. Mar Pollut Bull 22, 406-409.

Barghigiani, C., Ristori, T., Biagi, F., De Ranieri, S., 2000. Size related mercury accumulation in edible marine species from an area of the northerne Thyrrhenian sea. Water Air Soil Poll 124, 169-176.

Baun, A., Hartmann, N.B., Grieger, K., Kusk, K.O., 2008. Ecotoxicity of engineered nanoparticles to aquatic invertebrates: a brief review and recommendations for future toxicity testing. Ecotoxicology 17, 387-395.

Bebianno, M.J., Langston, W.J., Simkiss, K., 1992. Metallothionein induction in Littorina littorea (Mollusca: Prosobranchia) on exposure to cadmium. Journal of the Marine Biological Association of the UK 72, 329-342.

Beuerlein, K., Löhr, S., Westermann, B., Ruth, P., Schipp, R., 2002. Components of the cellular defense and detoxification system of the common cuttlefish Sepia officinalis (Mollusca, Cephalopoda). Tissue Cell 34, 390-396.

Beuerlein, K., Ruth, P., Scholz, F.R., Springer, J., Lieb, B., Gebauer, W., Westermann, B., Schmidtberg, H., Boletzky, S.v., Markl, J., Schipp, R., 2004. Blood cells and the biosynthesis of hemocyanin in Sepia embryos. Micron 35, 115-116.

Beuerlein, K., Schimmelpfennig, R., Westermann, B., Ruth, P., Schipp, R., 1998. Cytobiological studies on hemocyanin metabolism in the branchial heart complex of the common cuttlefish Sepia officinalis (Cephalopoda, Dibranchiata). Cell Tissue Res 292, 587-595.

Beuerlein, K., Schipp, R., 1998. Cytomorphological aspects on the response of branchial heart complex of Sepia officinalis L. (Cephalopoda) to xenobiotics and bacterial infection. Tissue Cell 30, 662-671.

Blanc, A., Pinczon Du Sel, G., Daguzan, J., 1998. Habitat and diet of early stages of Sepia officinalis L. (Cephalopoda) in Morbihan bay, France. J Molluscan Stud 64, 263-274.

Bloom, N.S., 1992. On the chemical form of mercury in edible fish and marine invertebrate tissue. Can J Fish Aquat Sci 49, $1010-1017$.

Borges, A.V., Frankignoulle, M., 1999. Daily and seasonal variations of the partial pressure of $\mathrm{CO}_{2}$ in surface seawater along Belgian and southern Dutch coastal areas. J Mar Syst 19, 251-266.

Boucaud-Camou, E., 1972. Premières données sur l'infrastructure du foie de Sepia officinalis L. Bull Soc Zool Fr 97, 149-156.

Boucaud-Camou, E., Boucher-Rodoni, R., 1983. Feeding and digestion in cephalopods, in: Saleuddin, A.S.M., Wilbur, K.M. (Eds.), The Mollusca: Physiology Part 2. Academic Press, London, p. 149.

Boucaud-Camou, E., Yim, M., 1980. Fine structure and function of the digestive cell of Sepia officinalis (Mollusca: Cephalopoda). J Zool 191, 89-105.

Boucher-Rodoni, R., Boucaud-Camou, E., Mangold, K., 1987. Feeding and digestion, in: Boyle, P.R. (Ed.), Cephalopod Life Cycle. Academic Press, London, pp. 85-108.

Bustamante, P., 1998. Bioaccumulation des éléments traces chez les mollusques céphalopodes et bivalves pectinidés. Implication de leur biodisponibilité pour le transfert vers les prédateurs., Pôle Sciences et Technologie. Université de La Rochelle, La Rochelle, p. 295.

Bustamante, P., Bertrand, M., Boucaud-Camou, E., Miramand, P., 2006a. Subcellular distribution of Ag, Cd, Co, Cu, Fe, Mn, Pb, and Zn in the digestive gland of the common cuttlefish Sepia officinalis. J Shellfish Res 25, 987-993. 
Bustamante, P., Bocher, P., Chérel, Y., Miramand, P., Caurant, F., 2003. Distribution of trace elements in the tissues of benthic and pelagic fish from the Kerguelen Islands. Sci Total Environ 313, 25-39.

Bustamante, P., Caurant, F., Fowler, S.W., Miramand, P., 1998a. Cephalopods as a vector for the transfer of cadmium to top marine predators in the north-east Atlantic Ocean. Sci Total Environ 220, 71-80.

Bustamante, P., Cherel, Y., Caurant, F., Miramand, P., 1998b. Cadmium, copper and zinc in octopuses from Kerguelen Islands, Southern Indian Ocean. Polar Biol 19, 264-271.

Bustamante, P., Cosson, R.P., Gallien, I., Caurant, F., Miramand, P., 2002a. Cadmium detoxification processes in the digestive gland of cephalopods in relation to accumulated cadmium concentrations. Mar Environ Res 53, 227-241.

Bustamante, P., González, A.F., Rocha, F., Miramand, P., Guerra, A., 2008. Metal and metalloid concentrations in the giant squid Architeuthis dux from Iberian waters. Mar Environ Res 66, 278-287.

Bustamante, P., Grigiono, S., Boucher-Rodoni, R., Caurant, F., Miramand, P., 2000. Bioaccumulation of 12 trace elements in the tissues of the nautilus Nautilus macromphalus from New Caledonia. Mar Pollut Bull 8, 688-696.

Bustamante, P., Lahaye, V., Durnez, C., Churlaud, C., Caurant, F., 2006b. Total and organic Hg concentrations in cephalopods from the North Eastern Atlantic waters: Influence of geographical origin and feeding ecology. Sci Total Environ 368, 585-596.

Bustamante, P., Teyssié, J.-L., Danis, B., Fowler, S.W., Miramand, P., Cotret, O., Warnau, M., 2004. Uptake, transfer and distribution of silver and cobalt in tissues of the common cuttlefish Sepia officinalis at different stages of its life cycle. Mar Ecol Prog Ser 269, $185-195$.

Bustamante, P., Teyssié, J.-L., Fowler, S.W., Cotret, O., Danis, B., Miramand, P., Warnau, M., 2002b. Biokinetics of zinc and cadmium accumulation and depuration at different stages in the life cycle of the cuttlefish Sepia officinalis. Mar Ecol Prog Ser 231, $167-177$.

Caldeira, K., Wickett, M., 2005. Ocean model predictions of chemistry changes from carbon dioxide emissions to the atmosphere and ocean. J Geophys Res 110C, 1-12.

Castillo, L.V., Kawaguchi, S., Maita, Y., 1990. Evidence for the presence of heavy metal binding proteins in the squid Onychoteuthis borealijaponica, in: Hirano, R., Hanyu, I. (Eds.), The second Asian Fisheries Forum. Asian Fisheries Society, Manila, p. 991.

Castillo, L.V., Maita, Y., 1991. Isolation and partial characterisation of cadmium binding proteins from the oceanic squid Ommastrephes bartrami. Bulletin of the Faculty of Fisheries from Hokkaida University 42, 26-34.

Chouvelon, T., Spitz, J., Cherel, Y., Caurant, F., Sirmel, R., Mèndez Fernandez, P., Bustamante, P., 2011. Species and ontogenic-related differences in $\delta 13 C$ and $\delta 15 \mathrm{~N}$ values and $\mathrm{Hg}$ and $\mathrm{Cd}$ concentrations of cephalopods. Mar Ecol Prog Ser 433, 107-120.

Chouvelon, T., Warnau, M., Churlaud, C., Bustamante, P., 2008. Hg concentrations and related risk assessment in coral reef crustaceans, molluscs and fish from New Caledonia. Environ Pollut in press.

Clarke, M.R., 1996. Cephalopods as prey. III. Cetaceans. Philos Trans R Soc Lond B Biol Sci 351, 1053-1065.

Cossa, D., Lassus, P., 1989. Le Cadmium en milieu marin; biogéochimie et écotoxicologie in: IFREMER (Ed.), Rapport Scientifique et Technique, p. 110 pp.

Costa, P.M., Rodrigo, A.P., Costa, M.H., 2014. Microstructural and histochemical advances on the digestive gland of the common cuttlefish, Sepia officinalis L. Zoomorphology 133, 59-69.

Craig, S., Overnell, J., 2003. Metals in squid, Loligo forbesi, adults, eggs, and hatchlings. No evidence for a role for Cu- or Zn-metallothionein. Comp Biochem Physiol 34C, 311-317.

Croxall, J.P., Prince, P.A., 1996. Cephalopods as prey. I. Seabirds. Philos Trans R Soc Lond B Biol Sci 351, $1023-1043$. 
Cuénot, L., 1907. Fonctions absorbante et excrétrice du foie des Céphalopodes. Arch. Zool. exp. gén. 7, $227-245$.

Dallinger, R., 1993. Strategies of metal detoxification in terrestrial invertebrates, in: Dallinger, R., Rainbow, P.S. (Eds.), Ecotoxicology of metals in Invertebrates. CRC Press, Boca Raton, pp. 245-282.

Decleir, W., Lemaire, J., Richard, A., 1970. Determination of copper in embryos and very young specimens of Sepia officinalis L. Marine Biology 5, $256-258$.

Decleir, W., Vlaeminck, A., Geladi, P., Van Grieken, R., 1978. Determination of protein-bound copper and zinc in some organs of the cuttlefish Sepia officinalis L. Comp Biochem Physiol 60B, 347-350.

Finger, J.M., Smith, J.D., 1987. Molecular association of $\mathrm{Cu}, \mathrm{Zn}, \mathrm{Cd}$ and ${ }^{210} \mathrm{Po}$ in the digestive gland of the squid Nototodarus gouldi. Marine Biology 95 , 8791.

Fitzgerald, W.F., Lamborg, C.H., Hammerschmidt, C.R., 2007. Marine Biogeochemical cycling of Mercury. Chemical Reviews 107, 641-662.

Fleischer, M., Sarofim, A.F., Fassett, D.W., Hammond, P., Shacklette, H.T., Nisbet, I.C.T., Epstein, S., 1974. Environmental impact of Cadmium: a review by the panel on hazardous trace substances. Environ Health Perspect 7, 253-323.

George, S.G., Coombs, T.L., Pirie, B.J.S., 1982. Characterization of metal-containing granules from the kidney of the common mussel, Mytilus edulis. Biochim Biophys Acta 716, 61-71.

Guary, J.-C., Fowler, S.W., 1982. Experimental studies on the biokinetics of plutonium and americium in the cephalopod Octopus vulgaris. Mar Ecol Prog Ser 7, 37-43.

Guary, J.-C., Higgo, J.J.W., Cherry, R.D., Heyraud, M., 1981. High concentrations of transuranics and natural radioactive elements in the branchial hearts of the cephalopod Octopus vulgaris. Mar Ecol Prog Ser 4, 123-126.

Islam, M.S., Tanaka, M., 2004. Impacts of pollution on coastal and marine ecosystems including coastal and marine fisheries and approach for management: a review and synthesis. Mar Pollut Bull 48, 624-649.

Jereb, P., Allcock, A.L., Lefkaditou, E., Piatkowski, U., Hastie, L.C., Pierce, G.J., 2015. Cephalopod biology and fisheries in Europe: II. Species accounts, ICES Cooperative Research Report p. 360 pp.

Kawano, M., Matsushita, S., Inoue, T., Tanaka, H., Tatsukawa, R., 1986. Biological accumulation of chlordane compounds in marine organisms from the northern North Pacific and Bering Sea. Mar Pollut Bull 17, 512-516.

Klages, N.T.W., 1996. Cephalopods as prey. II. Seals. Philos Trans R Soc Lond B Biol Sci 351, 1045-1052.

Kojadinovic, J., Jackson, C.H., Cherel, Y., Jackson, G.D., Bustamante, P., 2011. Multi-elemental concentrations in the tissues of the oceanic squid Todarodes filippovae from Tasmania and the southern Indian Ocean. Ecotoxicol Environ Saf 74, 1238-1249.

Koyagani, T., Nakahara, M., Matsuba, M., Hirano, S., 1982. Metabolism of radionuclides in a cephalopod, lidako, Octopus ocellatus. J Radiat Res 23, 105118.

Koyama, J., Nanamori, N., Segawa, S., 2000. Bioaccumulation of waterborne and dietary cadmium by oval squid, Sepioteuthis lessoniana, and its distribution among organs. Mar Pollut Bull 40, 961-967.

Lacoue-Labarthe, T., Le Pabic, C., Bustamante, P., 2016. Ecotoxicology of early-life stages in the common cuttlefish Sepia officinalis: review and perspectives. Vie Milieu 66, 65-79.

Lacoue-Labarthe, T., Martin, S., Oberhänsli, F., Teyssié, J.-L., Jeffree, R., Gattuso, J.-P., Bustamante, P., 2012. Temperature and pCO 2 effect on the bioaccumulation of radionuclides and trace elements in the eggs of the common cuttlefish Sepia officinalis J Exp Mar Biol Ecol 413 , 45-49. 
Lacoue-Labarthe, T., Martin, S., Oberhänsli, F., Teyssie, J.L., Markich, S.J., Jeffree, R., Bustamante, P., 2009a. Effects of increased $p$ CO 2 and temperature on trace element (Ag, Cd and Zn) bioaccumulation in the eggs of the common cuttlefish, Sepia officinalis. Biogeosciences 6, $2561-2573$.

Lacoue-Labarthe, T., Oberhänsli, F.R., Teyssié, J.-L., Warnau, M., Koueta, N., Bustamante, P., 2008a. Differential bioaccumulation behaviour of Ag and Cd during the early development of the cuttlefish Sepia officinalis. Aquat Toxicol 86, 437-446.

Lacoue-Labarthe, T., Réveillac, E., Oberhänsli, F., Teyssié, J.-L., Jeffree, R., Gattuso, J.-P., 2011. Effects of ocean acidification on trace element accumulation in the early-life stages of squid Loligo vulgaris. Aquat Toxicol 105, 166-176.

Lacoue-Labarthe, T., Warnau, M., Oberhänsli, F., Teyssié, J.-L., Bustamante, P., 2009b. Bioaccumulation of inorganic Hg by the juvenile cuttlefish Sepia officinalis exposed to ${ }^{203} \mathrm{Hg}$ radiolabelled seawater and food. Aquat Biol 6, 91-98.

Lacoue-Labarthe, T., Warnau, M., Oberhänsli, F., Teyssié, J.-L., Jeffree, R.A., Bustamante, P., 2008b. First experiments on the maternal transfer of metals in the cuttlefish Sepia officinalis. Mar Pollut Bull 57, 826-831.

Lahaye, V., Bustamante, P., Spitz, J., Dabin, W., Das, K., Pierce, G.J., Caurant, F., 2005. Long-term dietary segregation of common dolphins Delphinus delphis in the Bay of Biscay, determined using cadmium as an ecological tracer. Mar Ecol Prog Ser 305, $275-285$.

Landrum, P.F., Lydy, M.J., Lee Ii, H., 1992. Toxicokinetics in aquatic systems: Model comparisons and use in hazard assessment. Environ Toxicol Chem 11, 1709-1725.

Le Pabic, C., Caplat, C., Lehodey, J.-P., Dallas, L., Koueta, N., 2015a. Physiological perturbations in juvenile cuttlefish Sepia officinalis induced by subchronic exposure to dissolved zinc. Mar Pollut Bull 95, 678-687.

Le Pabic, C., Caplat, C., Lehodey, J.-P., Milinkovitch, T., Koueta, N., Cosson, R.P., Bustamante, P., 2015b. Trace metal concentrations in post-hatching cuttlefish Sepia officinalis and consequences of dissolved zinc exposure. Aquat Toxicol 159, 23-35.

Mangold, K., 1989. Reproduction, croissance et durée de vie, in: Grassé, P.-P. (Ed.), Traité de Zoologie : Céphalopodes. Masson, Paris, pp. 493-552.

Marigomez, I., Orbea, A., Olabarrieta, I., Etxeberria, M., Cajaraville, M.P., 1996. Structural changes in the digestive lysosomal system of sentinel mussels as biomarkers of environmental stress in mussel-watch programmes. Comp Biochem Physiol 113C, 291-297.

Martin, J.H., Flegal, A.R., 1975. High copper concentrations in squid livers in association with elevated levels of silver, cadmium, and zinc. Marine Biology $30,51-55$.

Martoja, M., Marcaillou, C., 1993. Localisation cytologique du cuivre et de quelques autres métaux dans la glande digestive de la seiche, Sepia officinalis L. (Mollusque Céphalopode). Can J Fish Aquat Sci 50, 542-550.

McGeer, J.C., Niyogi, S., Smith, D.S., 2011. Cadmium of the Fish Physiology, in: Wood, C.M., Farrell, A.P., Brauner, C.J. (Eds.), Homeostasis and toxicology of non-essential metals. Academic Press, New York, USA, pp. 125-184.

Millero, F.J., Woosley, R., Ditrolo, B., Waters, J., 2009. Effect of ocean acidification on the speciation of metals in seawater. Oceanography $22,72-85$.

Miramand, P., Bentley, D., 1992. Concentration and distribution of heavy metals in tissues of two cephalopods, Eledone cirrhosa and Sepia officinalis from the French coast of the English Channel. Marine Biology 114, 407-414.

Miramand, P., Bustamante, P., Bentley, D., Koueta, N., 2006. Variation of heavy metal concentrations (Ag, Cd, Co, Cu, Fe, Pb, V, and Zn) during the life cycle of the common cuttlefish Sepia officinalis. Sci Total Environ 361, 132-143.

Miramand, P., Guary, J.-C., 1980. High concentrations of some heavy metals in tissues of mediterranean octopus. Bull Environ Contam Toxicol 24, 783-788.

Miramand, P., Guary, J.-C., 1981. Association of Americium-241 with adenochromes in the branchial hearts of the cephalopod Octopus vulgaris. Mar Ecol Prog Ser 4, 127-129. 
Monteiro, L.R., Porteiro, F.M., Gonçalves, J.M., 1992. Inter- and Intra-specific varaition of mercury levels in muscle of cephalopods from Azores. Arquipelago Life and Earth Sciences 10, 13-22.

Moore, M.N., 1990. Lysosomal cytochemistry in marine environmental monitoring. Histochem J 22, $187-191$.

Muirhead, S.J., Furness, R.W., 1988. Heavy metal concentrations in the tissues of seabirds from Gough Island, South Antlantic Ocean. Mar Pollut Bull 19, 278-283.

Naimo, T.J., 1995. A review of the effects of heavy metals on freshwater mussels. Ecotoxicology 4, $341-362$.

Nakahara, M., Koyanagi, T., Ueda, T., Shimizu, C., 1979. Peculiar accumulation of cobalt-60 by the branchial hearts of Octopus. Bull Jpn Soc Fish Oceanogr $45,539$.

Nakahara, M., Koyanagi, T., Ueda, T., Shimizu, C., 1982. Uptake and excretion of Cobalt-60 taken up from seawater by Octopus vulgaris. Bulletin of the Japanese Society of Scientific Fisheries 48, 1739-1744.

Nixon, M., Mangold, K., 1998. The early stage of Sepia officinalis, and the contrast with that of Octopus vulgaris (Cephalopoda). J Zool 245, 407-421.

O'Dor, R.K., Webber, D.M., 1986. The constraints on cephalopods: why squid aren't fish. Can J Zool 64, 1591-1605.

Pavičić, J., Raspor, B., Martinčić, 1993. Quantitative determination of metallothionein-like proteins in mussels. Methodological approach and field evaluation. Mar Biol 115, 435-444.

Pierce, G.J., Stowasser, G., Hastie, L.C., Bustamante, P., 2008. Geographic, seasonal and ontogenentic variation in cadmium and mercury concentrations in squid (Cephalopoda: Teuthoidea) from UK waters. Ecotoxicol Environ Saf 70, 422-432.

Poirier, R., Chichery, R., Dickel, L., 2004. Effects of rearing conditions on sand digging efficiency in juvenile cuttlefish. Behav Process 67, 273-279.

Pouil, S., Warnau, M., Oberhänsli, F., Teyssié, J.L., Bustamante, P., Metian, M., 2016. Influence of food on the assimilation of essential elements (Co, Mn, and Zn) by turbot Scophthalmus maximus. Mar Ecol Prog Ser 550, 207-218.

Raimundo, J., Caetano, M., Vale, C., 2004. Geographical variation and partition of metals in tissues of Octopus vulgaris along the Portuguese coast. Sci Total Environ 325, 71-81.

Raimundo, J., Costa, P.M., Vale, C., Costa, M.H., Moura, I., 2010a. DNA damage and metal accumulation in four tissues of feral Octopus vulgaris from two coastal areas in Portugal. Ecotoxicol Environ Saf 73, 1543-1547.

Raimundo, J., Costa, P.M., Vale, C., Costa, M.H., Moura, I., 2010b. Metallothioneins and trace elements in digestive gland, gills, kidney and gonads of Octopus vulgaris. Comp Biochem Physiol 152C, 139-146.

Raimundo, J., Pereira, P., Vale, C., Caetano, M., 2005. Fe, Zn, Cu and Cd concentrations in the digestive gland and muscle tissues of Octopus vulgaris and Sepia officinalis from two coastal areas in Portugal. Cienc Mar 31, 253-251.

Raimundo, J., Pereira, P.c., Vale, C., Canário, J.o., Gaspar, M., 2014. Relations between total mercury, methylmercury and selenium in five tissues of Sepia officinalis captured in the south Portuguese coast. Chemosphere 108, 190-196.

Raimundo, J., Vale, C., Canario, J., Branco, V., Moura, I., 2010c. Relations between mercury, methyl-mercury and selenium in tissues of Octopus vulgaris from the Portuguese coast. Environ Pollut 158, 2094-2100.

Raimundo, J., Vale, C., Duarte, R., Moura, I., 2008. Sub-cellular partitioning of $\mathrm{Zn}, \mathrm{Cu}, \mathrm{Cd}$ and Pb in the digestive gland of native Octopus vulgaris exposed to different metal concentrations (Portugal). Sci Total Environ 390, 410-416.

Raimundo, J., Vale, C., Duarte, R., Moura, I., 2010d. Association of $\mathrm{Zn}, \mathrm{Cu}, \mathrm{Cd}$ and Pb with protein fractions and sub-cellular partitioning in the digestive gland of Octopus vulgaris living in habitats with different metal levels. Chemosphere 81, 1314-1319. 
Rjeibi, M., Metian, M., Hajji, T., Guyot, T., Chaouacha-Chékir, R.B., Bustamante, P., 2015. Seasonal survey of contaminants (Cd and Hg) and micronutrients ( $\mathrm{Cu}$ and $\mathrm{Zn}$ ) in edible tissues of cephalopods from Tunisia: assessment of risk and nutritional benefits. J Food Sci 80, $199-206$.

Rocca, E., 1969. Copper distribution in Octopus vulgaris Lam. hepatopancreas. Comp Biochem Physiol 28, 67-82.

Rosa, I.C., Raimundo, J., Lopes, V.M., Brandão, C., Couto, A., Santos, C., Cabecinhas, A.S., Cereja, R., Calado, R., Caetano, M., Rosa, R., 2015. Cuttlefish capsule: An effective shield against contaminants in the wild. Chemosphere 135, 7-13.

Rossi, A., Pellegrini, D., Belcari, P., Barghigiani, C., 1993. Mercury in Eledone cirrhosa from the northern Tyrrhenian sea: Contents and relations with life cycle. Mar Pollut Bull 26, 683-686.

Ruth, P., Schimmelpfennig, R., Schipp, R., 1999. Comparative immunocytochemical investigations on the localization of haemocyanin synthesis in dibranchiate and tetrabranchiate cephalopods (Sepia and Nautilus), in: Olóriz, F., Rodriguez-Tovar, F.J. (Eds.), Advancing research in living and fossil cephalopods. Kluwer Academic/Plenum, New York, pp. 189-202.

Ruth, P., Schipp, R., Klüssendorf, 1988. Cytomorphology and copper content of the basal cells in the midgut gland of Nautilus (Cephalopoda, Tetrabranchiata). Zoomorphology 108, 1-11.

Salles, D., Roumezi, A., Lanceleur, L., Schäfer, J., Petit, J., Blanc, G., Coynel, A., Chiffoleau, J.-F., Auger, D., 2013. L’argent (Ag, nanoAg) comme contaminant émergent dans l'estuaire de la Gironde : évaluations scientifiques et gouvernance des risques. Environnement, Risques \& Santé 12, $317-323$.

Schipp, R., Hevert, F., 1978. Distribution of copper and iron in some central organs of Sepia officinalis (Cephalopoda). A comparative study by flameless atomic absorption and electron microscopy. Marine Biology 47, 391-399.

Seixas, S., Bustamante, P., Pierce, G., 2005. Accumulation of mercury in the tissues of the common octopus Octopus vulgaris (L.) in two localities on the Portuguese coast. Sci Total Environ 340, 113-122.

Semedo, M., Reis-Henriques, M.A., Rey-Salgueiro, L., Oliveira, M., delerue-Matos, C., Morais, S., Ferreira, M., 2012. Metal accumulation and oxidative stress biomarkers in octopus (Octopus vulgaris) from Northwest Atlantic. Sci Total Environ 433, 230-237.

Smith, J.D., Plues, L., Heyraud, M., Cherry, R.D., 1984. Concentrations of the elements Ag, Al, Ca, Cd, Cu, Fe, Mg, Mn, Pb and Zn, and the radionuclides ${ }^{210} \mathrm{~Pb}$ and ${ }^{210} \mathrm{Po}$ in the digestive gland of the squid Nototodarus gouldi. Mar Environ Res 13, 55-68.

Son, M.-H., Kim, J., Shin, E.-S., Seo, S.-h., Chang, Y.-S., 2015. Diastereoisomer- and species-specific distribution of hexabromocyclododecane (HBCD) in fish and marine invertebrates. J Hazard Mater 300, 114-120.

Stockdale, A., Tipping, E., Lofts, S., Mortimer, R.J., 2016. Effect of ocean acidification on organic and inorganic speciation of trace metals. Environ Sci Technol 50, 1906-1913.

Storelli, M.M., 2008. Potential human health risks from metals ( $\mathrm{Hg}, \mathrm{Cd}$, and $\mathrm{Pb}$ ) and polychlorinated biphenyls (PCBs) via seafood consumption: Estimation of target hazard quotients (THQs) and toxic equivalents (TEQs). Food Chem Toxicol 46, 2782-2788.

Storelli, M.M., Barone, G., Marcotrigiano, G.O., 2005. Cadmium in cephalopod molluscs: Implications for public health. J Food Prot 68, 577-580.

Storelli, M.M., Garofalo, R., Giungato, D., Giacominelli-Stuffler, R., 2010. Intake of essential and non-essential elements from consumption of octopus, cuttlefish and squid. Food Additives and Contaminants: Part B Surveillance 3, 14-18.

Storelli, M.M., Giacominelli-Stuffler, R., Storelli, A., Marcotrigiano, G.O., 2006. Cadmium and mercury in cephalopod molluscs: Estimated weekly intake. Food Addit Contam 23, 25-30.

Storelli, M.M., Marcotrigiano, G.O., 1999. Cadmium and total mercury in some cephalopods from the South Adriatic Sea (Italy). Food Addit Contam 16, 261265 . 
Tanabe, S., Tanaka, H., Tatsukawa, R., 1984. Polychlorobiphenyls, EDDT, and Hexachlorocyclohexane Isomers in the Western North Pacific Ecosystem. Arch Environ Contam Toxicol 13, 731-738.

Tanaka, T., Hayashi, Y., Ishizawa, M., 1983. Subcellular distribution and binding of heavy metals in the untreated liver of the squid; comparison with data from the livers of cadmium and silver exposed rats. Experientia 39, 746-748.

Thomann, R.V., 1981. Equilibrium model of fate of microcontaminants in diverse aquatic food chains. Can J Fish Aquat Sci 38, $280-296$.

Ueda, T., Nakahara, M., Ishii, T., 1979. Amount of trace elements in marine cephalopods. J Radiat Res 20, 338-342.

Ueda, T., Nakahara, M., Nakamura, R., Suzuki, Y., Shimizu, C., 1985. Accumulation of ${ }^{65} \mathrm{Zn}$ by octopus Octopus vulgaris. J Radiat Res $26,313-320$.

Ueno, D., Inoue, S., Ikeda, K., Tanaka, H., Yamada, H., Tanabe, S., 2003. Specific accumulation of polychlorinated biphenyls and organochlorine pesticides in Japanese common squid as a bioindicator. Environ Pollut 125, 227-235.

Viarengo, A., Canesi, L., Pertica, M., Mancinelli, G., Orunesu, M., 1988. Biochemical characterization of a Copper-thionein inlvolved in Cu accumulation in the lysosomes of the digestive gland of mussles exposed to the metal. Mar Environ Res 24, 163-166.

Viarengo, A., Nott, J.A., 1993. Mechanisms of heavy metal cation homeostasis in marine invertebrates. Comp Biochem Physiol 104C, 355-372.

Villanueva, R., Bustamante, P., 2006. Composition in essential and non-essential elements of early stages of cephalopods and dietary effects on the elemental profiles of Octopus vulgaris paralarvae. Aquaculture 261, 225-240.

Wallace, W.G., Lee, B.-G., Luoma, S.N., 2003. Subcellular compartmentalization of Cd and Zn in two bivalves. I. Significance of metal-sensitive fractions (MSF) and biologically detoxified metal (BDM). Mar Ecol Prog Ser 249, 183-197.

Wallace, W.G., Luoma, S.N., 2003. Subcellular compartmentalization of Cd and $\mathrm{Zn}$ in two bivalves. II. Significance of trophically available metal (TAM). Mar Ecol Prog Ser 257, 125-137.

Williams, C., 1996. Combatting marine pollution from land-based activities: Australian initiatives. Ocean \& Coastal Management 33, 87-112.

Won, J.H., Hong, S.H., Shim, W.J., Yim, U.H., Kim, G.B., 2010. Understanding the accumulation features of POPs in squid from the offshore waters of southeast Korea. Fish Sci 76, 325-331.

Yim, M., Boucaud-Camou, E., 1980. Cytological study of the post-embryonic development of the digestive gland of Sepia officinalis L. Mollusca: Cephalopoda. Arch Anat Microsc Morphol Exp 69, 59-79. 